\title{
Középső skálába terjedő, temporalis csontból kiinduló koleszteringranuloma
}

\author{
Jakab-Péter Kinga dr. ${ }^{1}$ - Tóth Arnold dr. ${ }^{2}$ - Barabás Márta Andrea dr. ${ }^{3}$ \\ Gerlinger Imre dr. ${ }^{1}$ - Lujber László dr. ${ }^{1}$
}

${ }^{1}$ Pécsi Tudományegyetem, Általános Orvostudományi Kar, Klinikai Központ, Fül-Orr-Gégészeti és Fej-, Nyaksebészeti Klinika, Pécs

${ }^{2}$ Pécsi Tudományegyetem, Általános Orvostudományi Kar, Klinikai Központ, Radiológiai Klinika, Pécs

${ }^{3}$ „Dr. Fogolyán Kristóf” Megyei Sürgősségi Kórház, Sepsiszentgyörgy, Románia

\begin{abstract}
Az esetismertetésben bemutatott betegünket több mint egy évtizeden át kezelték nem specifikus fejfájással. A bal oldali halántéklebenyben évekkel korábban arachnoidealis cystát diagnosztizáltak, de ezt a fejfájás etiológiájából többször is kizárták. A beteg purulens fülváladékozással került intézetünkbe, ahol krónikus gennyes középfülgyulladást és az antrumot kitöltő, a piramiscsont tegmenét destruáló és a középső koponyagödörbe törő koleszteringranulomát állapítottunk meg, elvetve a korábbi arachnoidealis cysta kórisméjét. Esetünk kapcsán a koleszteringranuloma kórképét, mútéti megoldását, differenciáldiagnosztikai problémáit és a kapcsolódó nemzetközi irodalmat ismertetjük. A beteg krónikus középfülgyulladását tympanoplastica során szanáltuk, a koleszteringranuloma intra- és extracranialis részét is transmastoidalis feltárás során két ülésben eltávolítottuk, és a sziklacsont tegmenjének csontos hiányát septumporc segítségével állítottuk helyre, így a másodlagosan kialakult iatrogén meningoencephalicus herniát megszüntettük. A beteg fejfájása a mútétet követően azonnal megszűnt. Krónikus gennyes középfülgyulladása szanálódott. Agyszövet hernializálódása, agyvízcsorgás, illetve meningitis nem alakult ki. Két évvel a mútét után teljesen panaszmentes a beteg. A nagy kiterjedésű, a középső koponyagödörben növekvő koleszteringranuloma súlyos komplikációkat okozhat, emiatt fokozott figyelmet és egyénre szabott mútéti megoldást, ellátást igényel.
\end{abstract}

Orv Hetil. 2019; 160(52): 2067-2072.

Kulcsszavak: koleszteringranuloma, meningoencephalicus hernia, krónikus gennyes középfülgyulladás, mútét

\section{Temporal bone cholesterol granuloma penetrating into the middle cranial fossa}

The authors present a case report of a patient who was treated conservatively for a non-specific headache for more than a decade, while an arachnoidal cyst in the middle cranial fossa, over the temporal bone tegmen was diagnosed, but ruled out as the cause of the headache. The patient was referred to our ENT department with left, purulent ear discharge. Besides a chronic purulent otitis media, a cholesterol granuloma occupying the antrum, eroding the tegmen of the pyramid bone and penetrating into the middle cranial fossa was diagnosed. Case presentation of a patient with cholesterol granuloma, surgical options, differential diagnostic problems, and a literature review are presented. Tympanoplasty with cortical mastoidectomy was carried out to treat the chronic purulent otitis media, and the cholesterol granuloma was removed during transmastoid craniotomy. The iatrogenic temporal meningo-encephalic tissue herniation was repaired and the bone defect of the tegmen was reconstructed with septal cartilage. The patient's headache diminished immediately after the surgery. The chronic ear discharge stopped, the cholesterol granuloma was excised completely and the cerebral herniation was repaired successfully. Neither CSF leak, nor further herniation or meningitis were noticed. Two years after the operation the patient is asymptomatic. A large cholesterol granuloma, eroding into the middle cranial fossa can cause serious complications, and needs a high level of attention besides individualized surgical treatment based on the surgeon's abilities and skills.

Keywords: cholesterol granuloma, meningo-encephalic herniation, chronic suppurative otitis media, surgery

Jakab-Péter K, Tóth A, Barabás MA, Gerlinger I, Lujber L. [Temporal bone cholesterol granuloma penetrating into the middle cranial fossa]. Orv Hetil. 2019; 160(52): 2067-2072.

(Beérkezett: 2019. június 19.; elfogadva: 2019. július 26.) 


\section{Rövidítések}

CT = (computed tomography) számítógépes tomográfia; MR $=($ magnetic resonance $)$ mágneses rezonancia

A koleszteringranuloma a szervezet idegentest-reakciója a koleszterinkristályokkal szemben, amelyek a vér és a környező szövetek lebomlása során keletkeznek. A szervezetben a leggyakrabban a temporalis csontban fordul elő koleszteringranuloma. Sokszor tünetmentesek, emiatt a legtöbbször mellékleletként kerülnek felfedezésre különböző középfülmütétek kapcsán. Specifikus tüneteket általában nem okoznak, ennek következtében hosszú időn át fokozatosan növekedve destruálhatják a környező képleteket. A temporalis csont koleszteringranulomáinak két típusos elhelyezkedése van: a középfül és a sziklacsont csúcsa. A középfület érintő koleszteringranulomák nagy méretre való növekedése ritka, a folyamat nagy kiterjedése fóleg a sziklacsont csúcsára lokalizálódó esetekben jellemző [1].

$\mathrm{Az}$ alábbiakban bemutatott esetben a beteg krónikus, nem specifikus fejfájás miatt tüneti kezelést kapott egy évtizeden át, miközben a korábban diagnosztizált temporalis arachnoidealis cystát a fejfájás oki tényezőjeként kizárták. Újonnan kialakult fülpanaszok részletes kivizsgálása kapcsán derült ki, hogy az arachnoidealis cysta valójában egy temporalis koleszteringranuloma, mely az antrumból indulva a középső koponyagödörbe tört, és krónikus középfülgyulladást tartott fenn. Esetismertetésünk kapcsán részletezzük a kórképeket, a diagnosztikus és terápiás lehetőségeket.

\section{Esetismertetés}

A 61 éves férfi beteg kb. két éve fennálló, a bal oldali temporalis régióra lokalizálódó, állandó, erôs fejfájással és mindkét oldali, változó időközönként megjelenő fülfolyással jelentkezett Klinikánkon 2016. 03. 08-án. A beteget több mint egy évtizeden át gyógyszeresen kezelték nem specifikus fejfájás miatt. A bal oldali temporalis régióban arachnoidealis cystát diagnosztizáltak korábban, melyről dokumentáció nem állt rendelkezésünkre, és a beteg elmondása szerint ezt a fejfájásának okaként egyértelmúen kizárták. Anamnézisében szerepelt, hogy a beteg gyermekkorában kétoldali antrotomia történt krónikus középfülgyulladás, purulens otorrhoea miatt. Füleiből évente 2-3 alkalommal bűzös váladékozást tapasztalt, ami lokális kezelésekre mindig megszünt, és ez a beteget különösebben nem zavarta. A betegnek mindkét oldalon kisfokú vezetéses halláscsökkenése volt a beszédfrekvenciákon, a magas hangok területén nagyfokú idegi komponenssel. A beteg elmondása szerint halláscsökkenése gyerekkora óta fennállt, de szubjektíven a bal fülének hallását tartotta rosszabbnak. Szédülése, neurológiai tünetei, meningealis izgalmi jelei nem voltak.

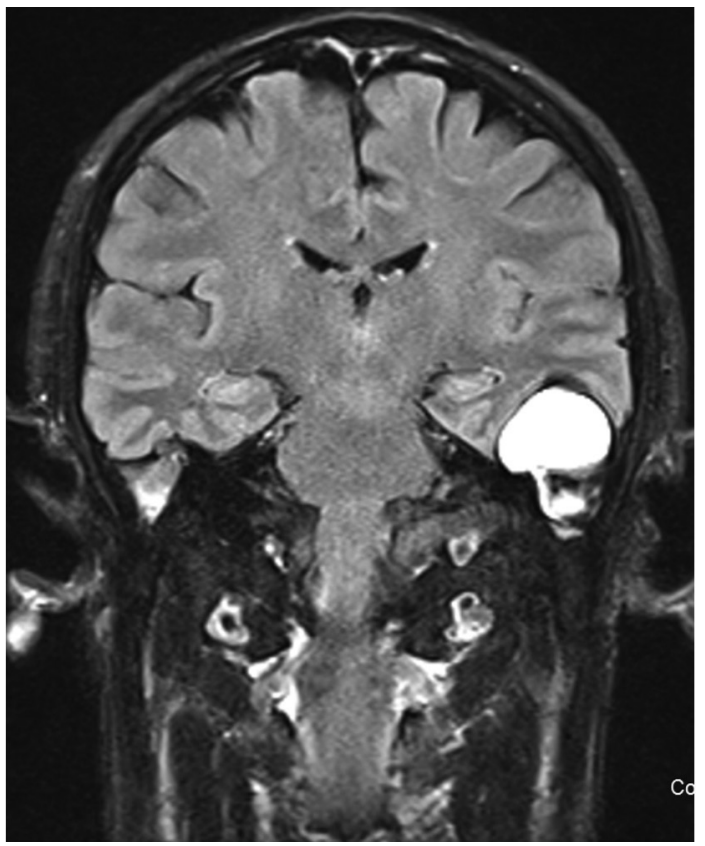

1. ábra

FLAIR-MR, koronális sík: a mastoidectomiás üreget, az antrumot kitöltő, az erodált tegmenen keresztül intracranialisan, extraduralisan terjedő, a temporalis lebenyen benyomatot képező erősen FLAIR hiperintenzív, homogén, jól körülírt képlet

FLAIR = folyadékcsillapító inverziós visszanyerése; $M R=$ mág neses rezonancia

A fizikális vizsgálat során mindkét oldalon centrális szubtotális dobhártya-perforáció volt látható, a bal oldalon minimális purulens dobüregi váladékozással.

A hozott, 2016. 01. 26-án történt kis felbontású teljeskoponya-CT a bal oldali processus mastoideusban egy temporalis csontot uzuráló, intracranialis irányba terjedő, jól körülhatárolt elváltozást írt le. Az elváltozás morfológiája alapján differenciáldiagnosztikai szempontból az arachnoidealis cysta mellett felmerült az epidermoid cysta és a koleszteringranuloma lehetősége is, aminek tisztázása céljából koponya-MR-vizsgálat is készült.

A 2016. 02. 10-én készült, hozott MR-felvételeken is, a CT-hez hasonlóan, a mastoidectomiás üreget, antrumot kitöltő és intracranialisan a temporalis régióban extraduralisan elhelyezkedő, a széli részeken meszesedést mutató cystosus folyamat ábrázolódott. Ezen felvételek arra engedtek következtetni, hogy korábban egyrekeszes, koleszteringranulomának megfelelő elváltozásról lehetett szó, mely az idő folyamán intracranialisan lefüződött, és a bevérzések különböző mértéke folytán két különálló képletként jelent meg a képalkotókon, eltérő jelintenzitást adva a felvételeken (1., 2. és 3. ábra).

2016. 08. 16-án, a Klinikánkon készült nagy felbontású sziklacsont-CT a fenti elváltozásokat szintén megerősítette, és látható volt az extra- és intracranialisan is elhelyezkedő $3 \mathrm{~cm}$ átmérőjü, hypodens, vékony fallal rendelkező, jól körülhatárolt elváltozás, mely a bal occipitalis és temporalis lebenyen benyomatot képezett. Emellett részletesen ábrázolódott a csonthiány a tegmen 


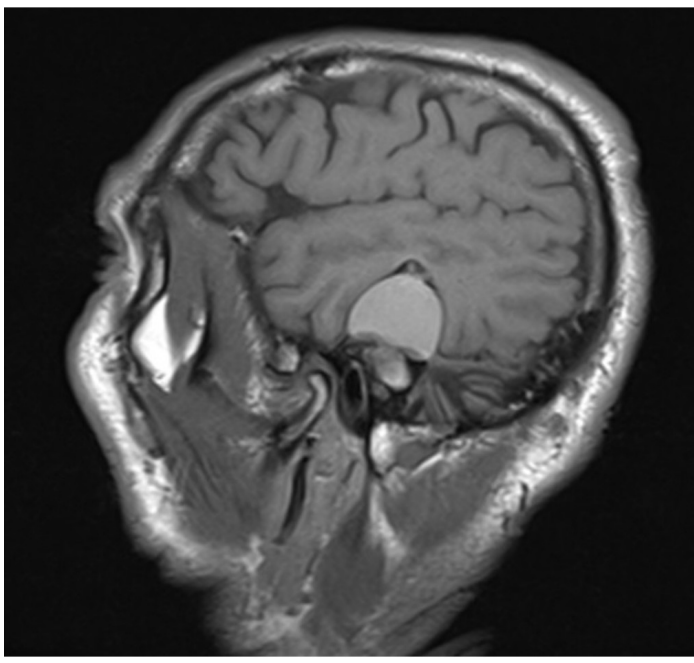

2. ábra

Tl-súlyozott koponya-MR, sagittalis sík: eltérő erôsségú, de magas Tl-jelintenzitást mutató képlet mind extra-, mind intracranialisan

$\mathrm{MR}$ = mágneses rezonancia

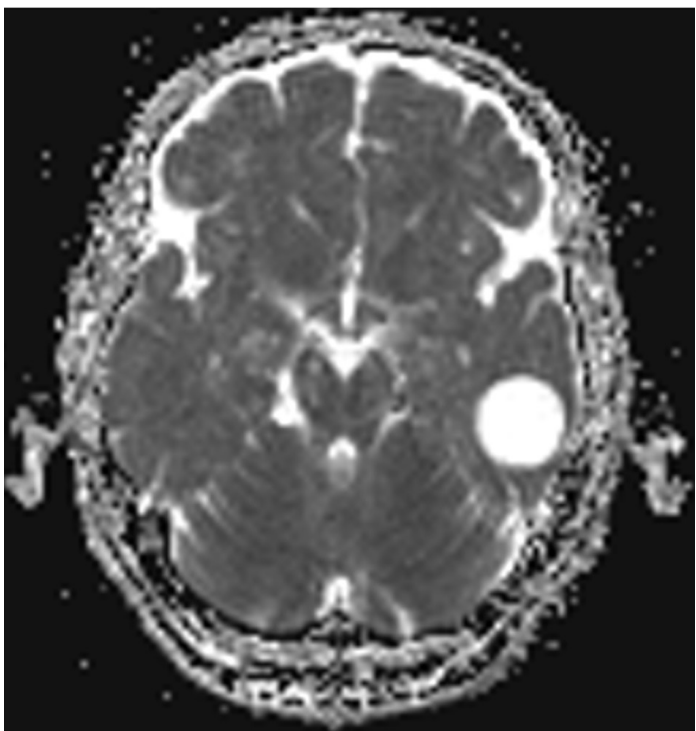

3. ábra

A becsült diffúziós koefficiens képen (ADC) a képlet homogén magas intenzitást mutat, mely magas diffuzivitásnak felel meg ezáltal a cholesteatoma kizárható

nagy területén, illetve a superior félkörös ívjárat csontos falának egy rövid szakaszán (4. ábra).

A beteg gennyes fülfolyása, állandó fejfájása (vezetô tünet) és a képalkotó vizsgálatokon látott elváltozások miatt a beteg beleegyezésével a mûtéti megoldás mellett döntöttünk.

Klinikánkon 2016. 09. 29-én, transmastoidalis feltárás során a mastoid üreget részben kitöltő többrekeszes, sưrú állagú cystosus képletet távolítottunk el. Ezt követően látható volt egy különálló második, nagy kiterjedésű, vaskos falú, pulzáló terime, mely a tegmenen keresztül a mastoid üregbe domborodott a középső skálából. Ezt a terimét megpungálva, majd megnyitva sárgás, sa-

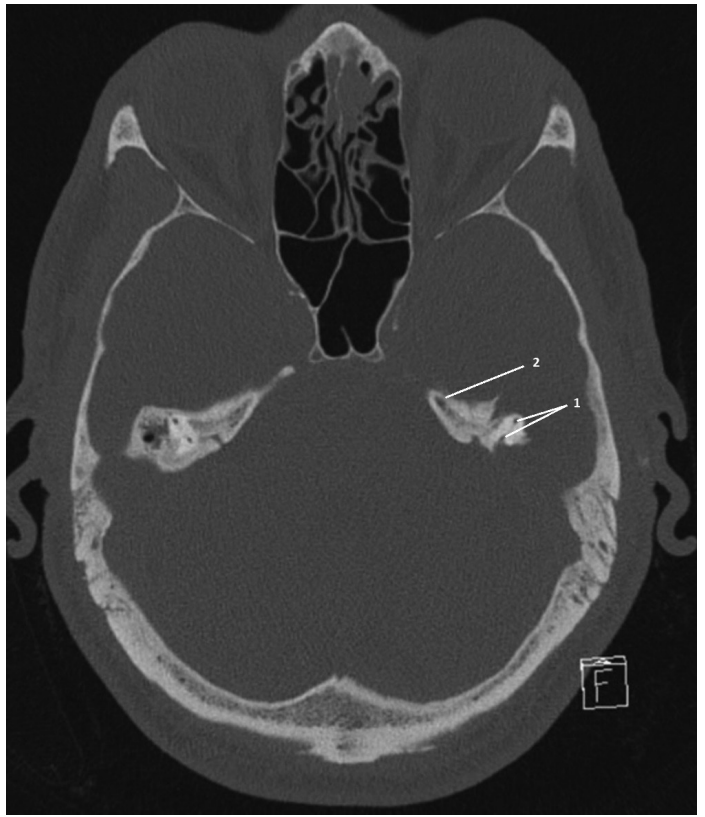

4. ábra

Preoperatív sziklacsont-HRCT, axiális sík: a superior félkörös ívjárat csontos fala egy rövid szakaszon destruált; 1) superior félkörös ívjárat, hátsó szakaszán a csontos fal destruált; 2) a sziklacsont csúcsi része

HRCT = nagy felbontású komputertomográfia

vós, nagy mennyiségú folyadékot tudtunk lebocsátani. A cystosus terime belseje sima felszínű és reakciómentes volt. A herniálódott terime körüli csontos tegment gyémántfúróval elvettük, és a vaskos falú cystosus képletet a duráról fokozatosan elkezdtük lefejteni. Az elváltozás nagy kiterjedése miatt kialakult nagyjából $2 \times 2 \mathrm{~cm}$-es csontostegmen-hiány, illetve a dura vékonysága, valamint a dura és a csont pótlására alkalmas szövetpótló anyagok hiánya miatt a mútét befejezése és késôbbi időpontban való folytatása mellett döntöttünk. Pár héttel az első mútétet követően, 2016. 11. 04-én, altatásban a betegtől septumplastica során septumporcot nyertünk, majd ismételten transmastoidalis behatolásból, az első mútét során hátrahagyott cystosus terime mastoidalis és intracranialis részét in toto reszekáltuk. Sikerült a durát intakt módon megőrizni, így durapótlásra nem volt szükség. A terime eltávolítása után a mastoid üregbe herniálódó durát és agyszövetet megfelelően méretezett septumporccal sikerült az intracranialis térbe visszahelyezni úgy, hogy a porcot körben mindenütt intracranialisan, de extraduralisan a tegmen csontpereme alá helyeztük.

Ezt követően a krónikus középfülgyulladást tympanoplastica során szanáltuk, az atrofizált és lyukas dobhártyát porccal „underlaid” módon rekonstruáltuk. A mútét szerkesztett változata online megtekinthető [2]. A mútétek során vett szövettan koleszteringranulomát és idegen test típusú granulomatosus reakciót véleményezett, lobos sarjadzással. 


\section{Eredmények}

A beteg fejfájása a mütét után azonnal megszűnt, és már a posztoperatív őrzőben erről számolt be a páciens. Fülfájdalom, fülfolyás nem alakult ki, hallása változatlan maradt.

A mútét után 4 hónappal készített kontroll-koponyaCT posztoperatív állapotot, a mastoid sejtrendszerben fedettséget írt le, mely klinikailag hegnek felelt meg. Residualis koleszteringranulomára utaló elváltozást a CT nem mutatott, sem intracranialisan, sem pedig intramastoidalisan. Agyi herniatio nem volt megfigyelhető, az intracranialis és extracranialis teret elválasztó porc a mütét során behelyezett pozícióban volt. A mütét során az arcideg ágai nem sérültek, a nervus petrosus inferior nem került látótérbe, a betegnél funkcióvesztés nem volt megfigyelhető. A beteg több mint 2 éve teljesen panaszmentes, fejfájása nem tért vissza, fülfolyása, fülpanaszai megszüntek.

\section{Megbeszélés}

A koleszteringranuloma a vér lebomlásából származó koleszterinkristályok ellen fellépő idegen test típusú óriássejtes gyulladásos reakció következtében jön létre [3]. A koleszterin annak ellenére, hogy endogén anyag, az óriássejtek általi abszorbcióra relatíve rezisztens, emiatt felhalmozódhat, és térfoglaló módon növekedhet [1].

A szervezetben több helyen előfordulhat, úgymint a melléküregekben, a tüdőben, a pleurában, a mediastinumban, a peritoneumban, a pajzsmirigyben, az agyban, az orbitában, a herékben, a vesékben, a nyirokcsomókban, ám a leggyakoribb előfordulási helye mégis a temporalis csont $[4,5]$.

Az irodalomban több mechanizmust írtak le, amely a kialakulását magyarázhatja, azonban mind egy idegen test típusú, óriássejtes reakción alapul. Trauma vagy hypercholesterinaemia prediszponáló tényező lehet jelen. A legelfogadottabb elmélet szerint az érpályában keringő vér kijut a temporalis csont légtartó üregeibe, ezáltal elzáródáshoz, a pneumatisatio megszűnéséhez vezet. A levegő fokozatosan felszívódik, és szellőzés hiányában negatív nyomás keletkezik, ami további bevérzéseket okoz, a felgyülemlő hemosziderin és koleszterin pedig gyulladásos reakciót indít el. Kialakulásának hátterében jelen lehet a makrofágtevékenység elégtelensége is, amikor a zsírnemú anyagok lebontása és elszállítása nem a megszokott módon történik. A kijutott gyülemet idővel kötőszövetes tok veszi körül; a fibroblastok egy része a tokképződésben vesz részt, másik része degenerálódhat, további koleszterinképződést indítva el, s hozzájárulva a folyamat tumorszerú növekedéséhez. A folyamat progressziója csontdestrukciót is okozhat, mint esetünkben is megfigyelhető volt [6-8].

A klinikai tünetek megjelenése a folyamat előrehaladottságától függ, az elváltozás sokáig tünetmentes lehet. A sziklacsontban előforduló két lokalizáció közül fóleg a csúcsi elhelyezkedésre jellemző a tünetek hiánya, emiatt nagyobb méreteket ölthet ez a forma, szemben a dobüregi megjelenéssel, melynél a környező képletek viszonylag gyorsabb érintettsége miatt hamarabb megjelenhetnek a figyelemfelkeltő panaszok. A temporalis csont koleszteringranulomája számos kórképhez társulva is megjelenhet, mint a különböző típusú krónikus középfülgyulladások, az idiopathiás haemotympanon vagy a középfülre, mastoid antrumjára, külső hallójáratra, a sziklacsont csúcsára lokalizált társbetegség, de létrejöhet fertőzéses kórelőzmény nélkül is [9]. Esetünkben a krónikus mesotympanalis középfülgyulladás talaján alakulhatott ki.

Otoszkópos vizsgálat során a dobhártya kékes színeződést mutathat, esetünkben azonban a centrális szubtotális perforáció miatt ez a tünet nem volt jelen [1].

A leggyakoribb tünetek: halláscsökkenés, tinnitus, vertigo, fejfájás, arcrángás, arcparesztézia, fülfolyás, diplopia, arcizomgyengeség [3]. Esetünkben a betegnek semmilyen tünete nem volt a fejfájáson kívül, kivéve az évek óta fennálló kétoldali halláscsökkenést és a változó intenzitású, általában enyhe fülfolyást. A hypacusis és az otorrhoea a beteg gyerekkora óta ismert kétoldali krónikus középfülgyulladás jellegzetes tüneteit képezték, emiatt ezeknek a tüneteknek jelentőséget a fejájás kapcsán senki sem tulajdonított.

Korábban a koleszteringranuloma csupán patológiai diagnózist jelentett, ma már azonban a CT- és az MRvizsgálatok lehetővé teszik a klinikai diagnózist is. CT-vel meghatározható a laesio pontos helye, ám a koleszteringranuloma és a cholesteatoma CT-morfológiája hasonló. Mindkettő éles határú, hasonló denzitású, és egyik sem halmozza a kontrasztanyagot. MR-vizsgálat segítségével elkülöníthető a két elváltozás egymástól, valamint más neoplasmák differenciáldiagnosztikájára is alkalmas. A koleszteringranuloma a T1- és T2-súlyozott felvételeken is magas jelintenzitást mutat, ami a koleszterin és a jelen levő fehérjetartalom paramágneses hatásának a következménye, mint ez esetünkben is látható volt. Ezzel szemben a cholesteatoma Tl-súlyozott felvételeken izovagy hipointenzív, és magas jelintenzitást mutat a T2súlyozott felvételeken [10-12].

Makroszkópos megjelenését illetően kerekded, ovális elváltozás vastag, fibrosus fallal, sárgás-barnás színú folyadékkal telve [7]. Tulajdonságait tekintve hasonló képletet távolítottunk el a mútétek során, és a koleszteringranuloma diagnózisát a szövettan is megerősítette.

Mikroszkóposan az elváltozás nagyszámú koleszterinkristályból áll, melyeket több sejtmagvú óriássejtek vesznek körbe, és fibrosus granulációs szövetbe vannak beágyazva; makrofágok és számos kapilláris lehetnek még jelen [13].

Differenciáldiagnosztikai szempontból gondolni kell a magas jugularis bulbusra vagy carotis interna dehiscentiára, cholesteatomára, különböző középfültumorokra, haemotympanonra, encephalokelére, arachnoidealis cystára, éreredetü malformációkra [3, 14]. Esetünkben 
az intracranialisan terjedő, intra- és extracranialisan különböző intenzitást mutató képletek miatt elsősorban az arachnoidealis cysta merült fel differenciáldiagnózisként, elkülönítésére azonban az MR-felvételek nyújtottak támpontot a dura helyzete és a jelintenzitásban mutatkozó különbségek által.

$\mathrm{Az}$ esetek többségében a koleszteringranuloma nem igényel agresszív terápiás beavatkozást. A kezelés függ a laesio helyétől, a tünetektől, a komplikációk jelenlététől, a társuló betegségektől, a hallás állapotától. A panaszokat okozó sziklacsontcsúcsi elváltozásokat a meningitis veszélye miatt célszerü megoperálni, ilyenkor az endoszkópos drenázs biztosítása, a sinus sphenoidalisba történő drenázs vagy az infratemporalis fossa B-típusú mútétek közül választhatunk.

A beteg erős fejfájásos panaszára és a laesio kiterjedésére való tekintettel esetünkben is a sebészi kezelés mellett döntöttünk. Mútét hiányában az elváltozás fokozatos növekedése a panaszok további erôsödéséhez vezethetett volna, valamint fennállt az alábbi súlyos komplikációk megjelenésének veszélye: a belső fül destrukciója, liquorcsorgás, meningitis, cerebrospinalis fistula, agytályog és egyéb neurológiai tünetek [1]. A folyamat már esetünkben is a hátsó félkörös ívjáratot megnyitva, a labyrinthot szabaddá tette, ami súlyos hallás- és egyensúlyproblémákat okozhatott volna.

Betegünknél az első mútétet követően, az intra- és extracranialis üregek tág kommunikációja miatt - miután eltávolítottuk a mastoid üreget kitöltő cystosus terimét - megszűnt ennek „alátamasztó” szerepe, így a tegmen nagy részén fennálló csonthiányon át a második mütétkor már egy iatrogén meningoencephalicus herniával is szembesültünk. A betegnek ez akkor még panaszokat nem okozott, de hosszú távon tünetekkel járt volna. Ennek a másodlagosan kialakult patológiás elváltozásnak az előfordulása meglehetősen ritka. A csontos tegmen hiánya önmagában nem elegendő a hernia kialakulásához, ugyanis az ép dura képes megtartani az agyállományt akár nagyobb csonthiány esetén is [15]. Esetünkben a dura rendkívül vékony és gyenge volt, valószínúleg az éveken át tartó gyulladásos folyamat, illetve a koleszteringranuloma mechanikai nyomása miatt. Nem csoda, hogy a nagy kiterjedésű tegmenen levő csonthiányt ez a meggyengült dura nem tudta kompenzálni és helyén tartani az intracranialis képleteket.

A temporalis meningoencephalicus hernia is gyakran tünetmentes, vagy csak diszkrét panaszokat okoz, mint a fül teltségérzése, halláscsökkenés, fülzúgás [16]. Betegünknél a mútétek előtt a mastoidból származó, nagy kiterjedésű koleszteringranuloma transtegmentalisan, epiduralisan, „homokóra-szerúen” nyomult a középső koponyagödörbe. Miután az első mütétet követően a koleszteringranuloma mastoidalis részét eltávolítottuk, illetve részben reszekáltuk az intracranialis részt is, a maradék koleszteringranuloma a gyengébb ellenállás felé, a mastoid üregbe húzta magával a durát és az agyszövetet, „igazi” meningoencephalicus hernia képét alakítva ki.
Ennek ellenére betegünk a két mütét között semmilyen új keletú panaszt nem észlelt, fejfájása pedig már az első mütét után megszünt.

A meningoencephalicus hernia kezelése általában mütéti. A sebészi beavatkozás típusa függ az elváltozás méretétől, helyétől, a társuló fülfolyamatoktól, a beteg hallásától és a sebész tapasztalatától [17]. A patológiás folyamat mútétileg elérhető középső skála craniotomiás feltáráson át, mini középső skála behatolásból, transmastoid behatolásból vagy kombinált középső skálatransmastoid behatolásokból is $[15,18]$. A dura, illetve csonthiány pótolható autológ, heterológ vagy alloplasztikus anyagokkal vagy ezek kombinációjával [19].

A subtemporalis, középső skála felőli megközelítés volt az első mütéti technika, amelyet javasoltak a tegmen hiányának helyreállítására, és máig ez a legelterjedtebb megoldás az idegsebészek köreiben [20]. Előnye, hogy jobb hozzáférést biztosít a sziklacsont superior-anterior részéhez, a hallást nem befolyásolja, csökkent a felülfertőződés veszélyének lehetősége a fertőzött középfül felől. Hátránya az invazív jellege és a magasabb mortalitása, emiatt Sanna és mtsai javasolják, hogy a subtemporalis behatolást csak azon spontán meningoencephalicus herniák megoldására alkalmazzák, ahol intakt a hallás [21].

Kisebb tegmendefektusok megoldására alternatívát jelenthet a transmastoid megközelítés; esetünkben is ezt a behatolást alkalmaztuk a második mütét során, annak ellenére, hogy a csontdefektus nem volt kicsi, de a fennálló középfülgyulladás szanálása is a célunk volt. A transmastoidalis feltárás egyszerú, direkt utat biztosít az oldalsó koponyaalapra, minimális morbiditással jár, azonban a mütét során a hallócsontláncolat sérülése okán vezetéses halláscsökkenés alakulhat ki. Krónikus középfülgyulladás egyidejű fennállása esetén a meningoencephalicus hernia kezelésének nélkülözhetetlen lépése a tympanoplastica. A tegmendefektus három módszerrel zárható: „overlay” módszerrel, amikor a graftot a mastoidalis felszínre ragasztjuk. Ilyenkor az intracranialis terület érintetlen marad. Az „inlay” módszerrel a graft a dura és sziklacsont közé kerül, a „sandwich” technika az előbbi két módszert együttesen alkalmazza. Esetünkben az „inlay” módszer használata mellett döntöttünk. Alternatív esetben szubtotális petrosectomia is végezhető, melynek során obliteráljuk a fülkürtöt, és véglegesen lezárjuk a külső hallójáratot „cul-de-sac” módszer szerint $[21,22]$.

\section{Következtetés}

Esetünkben a középfül nagy kiterjedésű, agresszív koleszteringranulomáját ismertettük, mely széles alapon a csontos tegmen destrukciója révén, a középső koponyagödörbe terjedt. A temporalis csont mastoidalis részének ilyen kiterjedésű koleszteringranulomája veszélyes, komoly szövődményeket okozhat, mint például a belső fül károsítása, a folyamat intracranium felé való továbbterje- 
dése és különböző fistulák megjelenése. A folyamat felismerése és megfelelő kezelése elengedhetetlen. A tünetek és a képalkotó vizsgálatok indokolták a középfül feltárását, a folyamat kiterjedésének megítélését és mútéti szanálását. A helyes terápiás döntést a beteg panaszmentessé válása jól alátámasztotta. Az ilyen elváltozások sebészi ellátásának során egyénre szabott mütéti megoldásokra lehet szükség a folyamat kiterjedésétől és az operáló orvos tapasztalatától függően.

Anyagi támogatás: A cikk megírása, illetve a kapcsolódó kutatómunka anyagi támogatásban nem részesült.

Szerzői munkamegosztás: J.-P. K.: A kézirat megszövegezése, az irodalomkutatás elvégzése. T. A.: A képalkototó vizsgálatok felvételeinek leletezése. B. M. A.: A kézirat megszövegezése. G. I.: A kézirat lektorálása, szakmai véleményezése. L. L.: Az eset diagnosztizálása és mütéti kezelése, kutatómunka lefolytatása, a kézirat lektorálása, szakmai véleményezése. A cikk végleges változatát valamennyi szerző elolvasta és jóváhagyta.

Érdekeltségek: A szerzőknek nincsenek érdekeltségeik.

\section{Irodalom}

[1] Kuruma T, Tanigawa T, Uchida Y, et al. Large cholesterol granuloma of the middle ear eroding into the middle cranial fossa. Case Rep Otolaryngol. 2017; 2017: 4793786.

[2] Available from: https://youtu.be/6ZzMdYFe600 [accessed: July 26, 2019].

[3] Sanna M, Dispenza F, Mathur N, et al. Otoneurological management of petrous apex cholesterol granuloma. Am J Otolaryngol. 2009; 30: 407-414.

[4] Aferzon M, Millman B, O'Donnell TR, et al. Cholesterol granuloma of the frontal bone. Otolaryngol Head Neck Surg. 2002; 127: 578-581.

[5] Leon ME, Chavez C, Fyfe B, et al. Cholesterol granuloma of the maxillary sinus. Arch Pathol Lab Med. 2002; 126: 217-219.

[6] Jackler RK, Cho M. A new theory to explain the genesis of petrous apex cholesterol granuloma. Otol Neurotol. 2003; 24 : 96-106.

[7] Rinaldo A, Ferlito A, Cureoglu S, et al. Cholesterol granuloma of the temporal bone: a pathologic designation or a clinical diagnosis? Acta Otolaryngol. 2005; 125: 86-90.
[8] Leel-Össy L, Barla S, Török P, et al. Intracranial cholesterol granulomas. [Intracranialis koleszteringranulomák.] Ideggy Szle. 2002; 55: 5-14. [Hungarian]

[9] Ramadan O. Temporal bone cholesterol granuloma. J Otolaryngol ENT Res. 2016; 4: 00109.

[10] Martin N, Sterkers O, Mompoint D, et al. Cholesterol granulomas of the middle ear cavities: MR imaging. Radiology 1989; 172: 521-525.

[11] Rosenberg RA, Hammerschlag PE, Cohen NL, et al. Cholesteatoma vs. cholesterol granuloma of the petrous apex. Otolaryngol Head Neck Surg. 1986; 94: 322-327.

[12] Mosnier I, Cyna-Gorse F, Grayeli AB, et al. Management of cholesterol granulomas of the petrous apex based on clinical and radiologic evaluation. Otol Neurotol. 2002; 23: 522-528.

[13] Nager GT, Vanderveen TS. Cholesterol granuloma involving the temporal bone. Ann Otol Rhinol Laryngol. 1976; 85: 204-209.

[14] Farrior B, Kampsen E, Farrior JB. The positive pressure of cholesterol granuloma idiopathic blue eardrum. Differential diagnosis. Laryngoscope 1981; 91: 1286-1297.

[15] Sdano MT, Pensak ML. Temporal bone encephaloceles. Curr Opin Otolaryngol Head Neck Surg. 2005; 13: 287-289.

[16] Gladstone JP, Dodick DW. Isolated sudden-onset hearing loss as a manifestation of recurrent CSF leak. Cephalalgia 2005; 25: $550-553$.

[17] Grinblat G, Dandinarasaiah M, Prasad SC, et al. Temporal bone meningo-encephalic-herniation: etiological categorization and surgical strategy. Otol Neurotol. 2018; 39: 320-332.

[18] Egilmez OK, Hanege FM, Kalcioglu MT, et al. Tegmen tympani defect and brain herniation secondary to mastoid surgery: case presentation. Case Rep Otolaryngol. 2014; 2014: 756280.

[19] McMurphy AB, Oghalai JS. Repair of iatrogenic temporal lobe encephalocele after canal wall down mastoidectomy in the presence of active cholesteatoma. Otol Neurotol. 2005; 26: 587594.

[20] Dutt SN, Mirza S, Irving RM. Middle cranial fossa approach for the repair of spontaneous cerebrospinal fluid otorrhoea using autologous bone pate. Clin Otolaryngol Allied Sci. 2001; 26: 117123.

[21] Sanna M, Fois P, Russo A, et al. Management of meningoencephalic herniation of the temporal bone: personal experience and literature review. Laryngoscope 2009; 119: 1579-1585.

[22] Zanetti D, Garavello W, Gaini L. Transmastoid repair of temporal meningoencephaloceles and cerebrospinal fluid otorrhea. Otorhinolaryngol Clinics 2011; 3: 31-41.

(Jakab-Péter Kinga dr., Pécs, Munkácsy M. u. 2., 7621 e-mail: jakabpeterkinga@gmail.com)

A cikk a Creative Commons Attribution 4.0 International License (https://creativecommons.org/licenses/by/4.0/) feltételei szerint publikált Open Access közlemény, melynek szellemében a cikk bármilyen médiumban szabadon felhasználható, megosztható és újraközölhetö, feltéve, hogy az eredeti szerző és a közlés helye, illetve a CC License linkje és az esetlegesen végrehajtott módosítások feltüntetésre kerülnek. (SID_1) 